\title{
Pentagon turns to 'softer' sciences
}

\section{US defence research to focus more on biology, cybersecurity and social sciences to help win conflicts.}

By highlighting the limits of traditional military technology, the drawn-out conflicts in Iraq and Afghanistan have spurred the US defence department to shake up its US\$12-billion science and technology research programme. The defence research and engineering office, headquartered at the Pentagon in Washington DC, is overseeing a budget shift away from applied research that supports weapons and into areas such as biology, computer science and the social sciences. All of these have "a potential for being game-changers" on the battlefield, says Zachary Lemnios, the defence department's chief technology officer and director of defence research and engineering.

Lemnios, who is nearing the end of his first year as research director, recently testified before Congress for the first time since he was confirmed for his position, and answered questions from Nature about his scientific priorities. He says that the new emphasis will have reverberations outside the Pentagon, noting that US universities will receive more than half of the $\$ 1.8$ billion that the defence department will spend on basic research in the current fiscal year. "Basic research funding not only leads to the next generation of technology but, just as importantly, supports a pipeline of researchers and graduate students," he says.

Among the areas that are fast becoming a priority for the Pentagon is synthetic biology, which seeks to build new organisms or re-engineer existing ones to perform specific functions. Lemnios says that the Pentagon is interested in understanding "how organisms sense and respond to stimuli - such as chemicals, ions and metals, or electrical, magnetic, optical and mechanical impulses - at a genetic level". That knowledge, he says, could help researchers to design "living sentinels" that can monitor the presence of explosives or chemical pollutants. "We can also develop tools that will allow us to detect adversarial uses of synthetic biology," he says.

According to Lemnios, the Office of Naval Research in Arlington, Virginia, is looking at how to biosynthesize targeted antibiotics that work by sensing and attacking specific pathogens. President Barack Obama's proposed budget for next year would also provide $\$ 20$ million to the Defense Advanced Research Projects Agency (DARPA), another research arm of the Pentagon, to fund work in synthetic biology.

As potential adversaries of the United States strengthen their abilities to attack computer networks, cybersecurity is another growing

Afghanistan, the Pentagon now believes that understanding cultural dynamics is at least as important as weapons. Consequently, Lemnios is ramping up funding in social-science projects, including a model developed by Los Alamos National Laboratory in New Mexico to simulate the opium trade in Afghanistan and analyse the effectiveness of efforts to combat it. The office is also supporting a project at the University of Chicago, Illinois, to model and predict potential conflicts.

Not all social scientists welcome the Pentagon's support, particularly if they are not happy with the direction that the military pushes the research. "There's something that happens when social science enters into this militarized model; all the rough edges, no matter how complicated, are smoothed, and the models themselves become pretty simplistic," says David Price, a cultural anthropologist at Saint Martin's University in Lacey, Washington state. "I worry in general what's happening to social science; new funding programmes like this are out there, while money for basic social science has gone away."

In the 1960s and 1970s, the office now headed by Lemnios held immense power in the Pentagon, but in recent

priority in the defence department's research portfolio, says Lemnios. He and the director of the Intelligence Advanced Research Projects Activity, Lisa Porter, last summer launched a joint study to look at where cybersecurity research dollars could be best spent. The results are feeding into a proposal to Congress for a new $\$ 200$-million research and technology pro-

"New funding programmes
like this are out there, while
money for basic social
science has gone away."
gramme in cybersecurity. As part of that programme, Lemnios told a House of Representatives panel on $23 \mathrm{March}$, his office will sponsor research to "harden key network components; increase the military's ability to fight and survive during cyber attacks; disrupt nation-state level attack planning and execution; measure the state of cybersecurity; and explore and exploit new ideals in cyberwarfare".

The unconventional wars now being fought by the US military have also bolstered interest in the social sciences. With the military trying to stave off a growing insurgency in decades it has had more of an advisory role. "They controlled no budget; that was my experience with them," says Subrata Ghoshroy, a research associate in the Program in Science, Technology, and Society at the Massachusetts Institute of Technology in Cambridge, Massachusetts, and a former congressional staff member. "It was an organization without any teeth."

But the office has gained renewed stature in recent years, and Lemnios now has a role in evaluating the Pentagon's weapons. That means ensuring that the technology in new weapons is mature enough for combat, and speeding the development of new technologies, notes Guy Ben-Ari, a fellow at the Washington-based Center for Strategic and International Studies.

For a country that has troops fighting in Afghanistan and Iraq, focusing on moving science from the lab to the battlefield quickly is critical, says Ben-Ari. “They're getting shot at today."

Sharon Weinberger 